\title{
Strategi Pemerintah Daerah dalam Meningkatkan Kualitas Pelayanan Perpustakaan Daerah Kota Tangerang Selatan
}

\author{
Dedek Kumara ${ }^{1}$ \\ ${ }^{1}$ Program Studi Manajemen, Universitas Pamulang, Indonesia \\ Email: kumara.dedek@gmail.com
}

\begin{abstract}
ABSTRAK
Penelitian ini ingin melihat lebih jauh bagaimana perpustakaan daerah dapat meningkatkan pelayanannya terhadap masyarakat melalui pengembangan rencana strategis. Penelitian ini bertujuan untuk: (1) mengetahui kondisi lingkungan internal dan eksternal Perpustakaan Daerah Kota Tangerang Selatan; (2) mengidentifikasi rumusan strategi berbasis analisis SWOT bagi perencanaan strategis jangka pendek dan jangka panjang Perpustakaan Daerah Kota Tangerang Selatan; dan (3) menganalisis proses strategi Perpustakaan Daerah Kota Tangerang Selatan. Model dan metode peneltian ini bersifat deskriptif-kualitatif. Metode analisis data yang digunakan bersifat induktif, mengacu pada Miles $\mathcal{E}$ Huberman model. Teknik pengumpulan data yang digunakan adalah observasi partisipatif, wawancara mendalam, dan dokumentasi. Hasil penelitian ini menunjukkan bahwa pengembangan lingkungan eksternal dilakukan dengan cara memberi kesempatan kepada masyarakat untuk mengikuti pendidikan dan pelatihan tentang perpustakaan, meningkatkan jumlah pengguna, dan menjadikan perpustakaan sebagai pusat informasi bagi masyarakat. Sedangkan pengembangan lingkungan internal dilakukan dengan cara meningkatkan pelayanan perpustakaan, optimalisasi perawatan koleksi, dan memberikan formasi yang sesuai pada SDM yang ada. Adapun strategi intensif dapat dilakukan melalui penetrasi pasar, pengembangan pasar, dan pengembangan produk, sementara strategi alternatif dapat dilakukan dengan menambah tenaga pustakawan perpustakaan.
\end{abstract}

Kata Kunci: Analisis SWOT, perencanaan strategis, perpustakaan daerah

ABSTRACT

This research would like to see further how regional libraries can improve their services to the public through the development of strategic plans. This study aims to: (1) know the internal and external environmental conditions of South Tangerang City Regional Library; (2) identify the strategy formulation based on SWOT analysis for short and long term strategic planning of South Tangerang City Regional Library; and (3) analyzing the strategy process of South Tangerang City Regional Library. Model and method of this research is descriptivequalitative. The data analysis method used is inductive, referring to Miles \& Huberman model. Data collection techniques used were participative observation, in-depth interviews, and documentation. The results of this study indicate that the development of the external environment is pursued by providing opportunities for the community to follow education and training about the library, increasing the number of users, and make the library as the information center for the community. While the development of the internal environment is pursued by improving library services, optimization of collection maintenance, and provide appropriate formation on existing human resources. The intensive strategy can be done through market penetration, market development, and product development, while alternative strategies can be done by adding librarians.

Keywords: SWOT analysis, strategic planning, regional library

Citation : Kumara, Dedek. 2018. “Tata Kelola Pemerintahan Daerah Otonom Baru pada Kabupaten Pesisir Barat, Provinsi Lampung". Journal of Government and Civil Society, Vol. 2, No. 1, 63-87. 


\section{PENDAHULUAN}

Proses manajemen strategis digunakan secara efektif oleh berbagai organisasi nirlaba dan organisasi pemerintah, seperti palang merah, kamar dagang, lembaga pendidikan, lembaga kesehatan, fasilitas umum, perpustakaan, dan badan-badan pemerintah. Konsepkonsep manajemen dan perencanaan strategis diperlukan secara luas dan digunakan untuk memampukan berbagai organisasi pemerintah bekerja secara lebih efektif dan efisien (David, 2010).

Perencanaan strategis menentukan tahapan perencanaan lain dalam perusahaan. Perencanaanstrategis tergantung pada pendefinisian misi perusahaan yang jelas, penetapan tujuan perusahaan yang menunjang perancangan portofolio bisnis yang baik, dan pengkoordinasian strategi fungsional (Kotler \& Amrstrong, 2003).

Menurut Franklin (dalam Yusri, 2011) organisasi nonprofit harus menggunakan pendekatan yang lebih strategis, lebih efisien, dan lebih efektif untuk mendorong kinerja organisasi yang lebih baik. Salah satu organisasi nonprofit yang melaksanakan perencanaan strategis adalah perpustakaan.Sebagai organisasi yang berkecimpung dalam pengelolaan, penyimpanan, dan penyebaran informasi, perpustakaan harus menyadari setiap perubahan dan perkembangan yang terjadi di sekitar lingkungan perpustakaan.

Perpustakaan mempunyai arti sebagai suatu tempat yang didalamnya terdapat kegiatanpenghimpunan, pengolahan, dan penyebarluasan (pelayanan) segala macam informasi, baik yang tercetak maupun yang terekam dalam berbagai media, seperti buku, majalah, surat kabar, film, kaset, tape recorder, video, komputer, dan bahan pustaka lainnya (Pawit, 2005).

Menurut Endang (2009) perpustakaanmerupakan suatu usaha jasa yang memberikanlayanan dengan menyediakan informasi yang dapat digunakan oleh masyarakat secara tepat dan merata sehingga semua lapisan masyarakat dapat menikmati informasi yang disediakan oleh perpustakaan. Sementara menurut Djumargio (2010) perpustakaan merupakanmedia yang menghubungkan antara sumber informasi dan ilmu pengetahuan melalui koleksi yang dimilikinya dengan para pemustaka. Perpustakaan mempunyai peran sebagai sarana untuk menjalin komunikasi antara pemustaka dan dengan penyelenggara perpustakaan sehingga terwujud dalam kelompok pembaca.

Perpustakaan adalah fasilitator untuk melakukan pendidikan sepanjang hayat, yaitu dengan memfasilitasi kemauan dan semangat belajar secara berkesinambungan dan penyediaan berbagai jenis layanan, seperti layanan sirkulasi, layanan referensi, layanan pendidikan, layanan perpustakaan keliling, layanan kerja sama antarperpustakaan (Muljono, 2007). 
Di samping itu, peningkatan kebutuhan informasi pelajar dan masyarakat daerah merupakan suatu aspek penting yang harus dipertimbangkan oleh perpustakaan daerah dalam menghadapi kenyataan, di mana perpustakaan bukan satu-satunya lembaga penyedia informasi bagi seluruh pelajar dan masyarakat, karena masyarakat dapat mencari informasi yang mereka butuhkan melalui internet (Yusri, 2011).

Dalam konteks peranpengembangan strategis Perpustakaan Daerah Kota Tangerang Selatan, peneliti ingin melihat lebih jauh bagaimana latar belakang perpustakaan daerah dapat melayani jasa terhadap masyarakat melalui rencana strategis dari perpustakaan. Karena itu, penelitian ini bertujuan untuk: (1) mengetahui kondisi lingkungan internal dan eksternal Perpustakaan Daerah Kota Tangerang Selatan; (2) mengidentifikasi rumusan strategi berbasis analisis SWOT bagi perencanaan strategis jangka pendek dan jangka panjang Perpustakaan Daerah Kota Tangerang Selatan; dan (3) menganalisis proses strategi Perpustakaan Daerah Kota Tangerang Selatan.

Beberapa penelitian terdahulu yang terkait dengan penelitian ini antara lain dilakukan oleh Fahmi (2011)yang membahas tentang perencanaan strategis pada Perpustakaan STAIN Padangsidimpuan yang bertujuan untuk:(1) mengetahui kondisi lingkungan internal dan eksternal Perpustakaan Padangsidimpuan; (2) menganalisis kekuatan, kelemahan, peluang, dan ancaman yang dihadapi Perpustakaan Padangsidimpuan; dan (3) mengidentifikasi rumusan strategi berbasis analisis SWOT bagi perencanaan strategis jangka pendek dan jangka panjang pada Perpustakaan Padangsidimpuan. Penelitian lainnya adalah penelitian yang dilakukan Rodiah (2011) terhadap Perpustakaan Daerah Kota Bekasi. Tujuan penelitian tersebut adalah untuk mengidentifikasi pengelolaan perpustakaan oleh Kapusda Kota Bekasi yang ditinjau dari penerapan fungsi manajemen strategis dan fungsi perencanaan.

\section{KERANGKA TEORETIS \\ Perencanaan}

Perencanaan merupakan jembatan yang penting antara masa kini dan masa depan yang mampu meningkatkan kemungkinan tercapainya hasil yang diinginkan. Perencanaan adalah awal dari proses di mana seorang individu atau sebuah bisnis bisa mengubah impian menjadi kenyataan (pencapaiaan). Perencanaan memampukan orang untuk menghindari jebakan bekerja sangat keras tetapi mendapatkan sangat sedikit (David, 2010).

Menurut Steurt dan Moran (dalam Fahmi, 2011), perencanaan adalah inti dari seluruh kegiatan manajemen, karena efektivitas perencanaan direfleksikan pada setiap bagian proses pengembangan sebuah organisasi. Perencanaan menentukan proses pengembangan dan pemeliharaan yang cocok antara sasaran serta kemampuan organisasi dan peluang yang berubah-ubah (Kotler \& Amstrong, 2003). 
Perencanaan memampukan perusahaan untuk mempertimbangkan berbagai faktor yang relevan dan berfokus pada hal penting. Perencanaan membantu perusahaan untuk melakukan perubahan yang dibutuhkan dan menyimpan sumberdayanya, menghindari pemborosan atau menyia-nyiakan sumberdaya ekologis, memperolehlaba yang sesuai, dan digolongkan sebagai perusahaan efektif dan bermanfaat (David, 2010).

Menurut Kotler dan Armstrong (2003) proses perencanaan sama pentingnya dengan rencana yang dihasilkan. Perencanaan mendorong manajemen untuk berpikir secara sitematis mengenai apa yang telah terjadi, apa yang sedang terjadi, dan apa yang mungkin akan terjadi. Perencanaan memaksa perusahaan untuk mempertajam tujuan dan kebijakannya, menciptakan koordinasi usaha-usaha perusahaan secara lebih baik, dan memberikan standar pengontrolan kinerja yang lebih jelas.

\section{Strategi}

Strategi merupakan sarana untuk mencapai tujuan jangka panjang, yaitu aksi potensial yang membutuhkan keputusan manajemen puncak dan sumberdaya perusahaan dalam jumlah yang besar. Selain itu, strategi memengaruhi perkembangan jangka panjang perusahaan yang berorientasi ke masa yang akan datang. Strategi mempunyai konsekuensi multifungsional atau multidivisional dan perlu mempertimbangkan baik faktor eksternal maupun internal yang dihadapi perusahaan (David, 2010).

Menurut Kotler dan Armstrong (2003) perusahaan atau organisasi harus melakukan pekerjaan yang lebih baik dari para pesaingnya dalam rangka memuaskan konsumen. Jadi, strategi harus disesuaikan dengan kebutuhan dan strategi pesaing. Merancang strategi-strategi yang bersaing dimulai dengan melakukan analisis pesaing secara lengkap.

Sementara menurut Weelan dan Hunger (dalam Juanita, 2009), strategi diartikan sebagai rencana utama yang komprehensif yang menyatakan bagaimana perusahaan mencapai misi dan tujuannya dengan cara memaksimalkan keunggulan kompetitif dan meminimalkan ketidakunggulan dengan memperkecil kerugian.

\section{Proses Perencanaan Strategis}

Proses strategis digunakan untuk memahami posisi strategis dari organisasi, memahami apa yang terjadi disekitar lingkungan organisasi dan memastikan hal tersebut berpengaruh atau tidak terhadap organisasi, memahami kekuatan (strength) dan kelemahan (weakness) organisasi serta memperkirakan apa yang diinginkan stakeholder. Proses strategi mengarahkan untuk membentuk suatu gambaran dari lingkungan yang memengaruhi organisasi untuk menentukan pilihan elemen strategis dari keseluruhan proses manajemen strategis (dalam Wedhasmara, 2008). 
Kegiatan yang paling penting dalam proses analisis adalah memahami seluruh informasi yang terdapat pada suatu kasus, menganalisis situasi untuk mengetahui isu apa yang sedang terjadi dan memutuskan tindakan apa yang harus segera dilakukan untuk memecahkan masalah (Rangkuti, 2013).

Menurut Wahyudi (dalam Fahmi, 2011) pokok masalah dari proses perencanaan strategis adalah bagaimana menghubungkan organisasi dengan lingkungannya dan menciptakan strategi yang cocok untuk mencapai misi organisasi. Proses strategi merupakan hal penting yang harus dikerjakan untuk menentukan bagaimana mencapai tujuan organisasi.

Organisasi dapat membangun sinergi melalui perencanaan. Sinergi terjadi manakala setiap orang bersatu sebagai tim yang tahu apa yang ingin dicapainya. Dengan menetapkan dan mengkomunikasikan tujuan-tujuan yang jelas, karyawan dan manajer dapat bekerja bersama kearah tujuan yang diinginkan. Sinergi perencanaan dan strategi dapat menghasilkan keunggulan kompetitif yang solid (David, 2010).

Kotler (2003) mendefinisikan perencanaan strategis sebagai proses untuk mengembangkan dan memelihara strategi yang cocok antara sasaran serta kemampuan organisasi dan peluang yang berubah-ubah. Perencanaan strategis menentukan tahapan perencanaan lain dalam perusahaan. Perencanaan strategis tergantung pada pendefinisian misi dan visi perusahaan yang jelas, penetapan tujuan perusahaan, perancangan portofolio bisnis yang baik, dan pengkoordinasian strategi yang fungsional.

Bryson (dalam Fahmi, 2011) mendefinisikan bahwa perencanaan strategis mencakup beberapa langkah atau tahapan yang masing-masing saling terkait. Langkah-langkah dalam proses perencanaan strategis atau Bryson's strategis change cycle adalah memprakarsai dan menyepakati suatu perencanaan strategis, mengidentifikasi mandat organisasi, memperjelas misi dan nilai-nilai organisasi, menilai lingkungan internal dan eksternal untuk mengidentifikasi kekuatan, kelemahan, peluang dan ancaman, mengidentifikasi isu-isu strategis yang dihadapi oleh organisasi, merumuskan berbagai strategi untuk menangani isu-isu tersebut, meninjau dan mengadopsi berbagai rencana strategis, menciptakan visi organisasi yang efektif untuk masa depan, mengembangkan proses implementasi yang efektif, penilaian kembali strategi-strategi dan proses perencanaan strategis.

Perencanaan strategi yang sangat baik secara teknis tidak akan ada banyak gunanya jika tidak diimplementasikan. Banyak organisasi cenderung mencurahkan banyak waktu, uang, dan usaha untuk mengembangkan rencana strategis, menjadikan sarana dan lingkungan yang dengannya rencana tersebut diimplementasikan sebagai hal sekunder untuk dipikirkan kemudian. Perubahan berlangsung melalui implementasi dan evaluasi, bukan melalui rencana (David, 2010). 


\section{Perpustakaan Umum}

Perpustakaan umum adalah sebuah perpustakaan atau sistem yang mencakup akses untuk sumber dan layanan perpustakaan yang gratis untuk semua kalangan, daerah, dan wilayah geografis yang didukung oleh masyarakat (dalam Rodiah, 2011).Menurut Sulistyo dan Basuki (dalam Asep, 2003) perpustakaan adalah ruangan, bagian sebuah gedung yang digunakan untuk menyimpan buku dan terbitan lainnya yang biasanya disimpan menurut tata susunan tertentu untuk digunakan pembaca. Semua koleksi atau bahan pustaka yang ada diperpustakaan disusun berdasarkan sistem tertentu dan digunakan untuk kepentingan belajar melalui kegiatan membaca dan mencari informasi bagi segenap masyarakat yang membutuhkannya (Pawit, 2007).

Perpustakaan tidak terlepas dari kata dasar pustaka yang berarti buku atau kitab. Dalam perkembangannya, perpustakaan adalah tempat untuk menyimpan bahan pustaka dalam bentuk cetak maupun noncetak yang diolah dan disajikan kepada pemakai. Perpustakaan pun dapat berfungsi sebagai pemberian informasi kepada pemakai untuk kepentingan riset dan pembelajaran (Indayati, 2008).

Berdasarkan UU No. 43 Tahun 2007 tentang Perpustakaan, jenis perpustakaan ada lima: perpustakaan nasional, perpustakaan umum, perpustakaan perguruan tinggi, perpustakaan sekolah, dan perpustakaan khusus. Salah satu yang akan dibahas dalam penelitian ini adalah perpustakaan umum. Perpustakaan umum dalam melayani masyarakat tidak mengenal batasan (Endang, 2009). Sedangkan Pawit (2007) mendefinisikan bahwa perpustakaan umum lebih disifati oleh karakteristik masyarakat penggunanya yang sangat heterogen, yang meliputi semua batas usia dan semua tingkatan. Jadi, tidak dibatasi oleh karakteristik sosiodemografi.

Menurut Sulistyo (dalam Endang, 2009) perpustakaan umum terdiri dari perpustakaan propinsi sampai desa atau kelurahan. Pendirian perpustakaan umum dibiayai oleh pemerintahan daerah, pemerintahan pusat atau organisasi lain yang diberikan kuasa untuk menjalankannya. Perpustakaan umum didirikan oleh dana umum dengan tujuan untuk melayani masyarakat.

Sedangkan fungsi perpustakaan berdasarkanUndang-Undang No. 43 adalah sebagai wahana pendidikan, penelitian, pelestarian, informasi, dan rekreasi untuk meningkatkan kecerdasan dan keberdayaan bangsa,bertujuan memberikan layanan kepada pemustaka, meningkatkan kegemaran membaca, serta memperluas wawasan dan pengetahuan untuk mencerdaskan kehidupan bangsa.

\section{Analisis SWOT}

SWOT adalah sebuah bentuk analisis situasi dan kondisi yang bersifat deskriptif. Analisis ini menempatkan situasi dan kondisi sebagai faktor masukan yang kemudian dikelompokkan menjadi empat komponen dasar:(1) strength, yaitusituasi atau kondisi 
yang merupakan kekuatan organisasi; (2)weakness, yaitu situasi atau kondisi kelemahan organisasi; (3)opportunity, yaitu situasi atau kondisi yang merupakan peluang di luar organisasi dan memberi peluang bagi organisasi untuk berkembang di masa depan; dan (4) threat, yaitu situasi atau kondisi yang merupakan ancaman terhadap organisasi yang datang dari luar dan dapat mengancam eksistensi organisasi dimasa depan (dalam Hendrawan, 2012).

Pearce dan Robinson (dalam Yusri, 2011) mendefinisikan bahwa SWOT adalah singkatan dari strengths (ancaman), weaknesses (kelemahan), opportunities (peluang), dan threats (ancaman). Kekuatan dan kelemahan yang dimaksud adalah kekuatan dan kelemahan yang secara internal dimiliki oleh organisasi, sedangkan peluang dan ancaman ialah faktor eksternal yang berada dilingkungan yang dihadapi organisasi tersebut.

Analisis SWOT adalah sebuah alat pencocokan penting yang membantu para manajer mengembangkan empat jenis strategi, strategi SO (kekuatan-peluang), strategi WO (kelemahan-peluang), strategi ST (kekuatan ancaman), dan strategi WT (kelemahanancaman). Mencocokkan faktor-faktor eksternal dan internal utama merupakan bagian tersulit dalam mengembangkan matriks SWOT dan membutuhkan penilaian yang baik dan tidak ada satupun panduan yang paling benar.

Kotler dan Keller (2010) mendefinisikan bahwa keseluruhan evaluasi tentang kekuatan, kelemahan, peluang, dan ancaman perusahaan disebut analisis SWOT. Analisis lingkungan eksternal (peluang dan ancaman) unit bisnis harus mengamati kekuatan lingkungan makro yang utama dan faktor lingkungan mikro yang signifikan, yang memengaruhi kemampuannya dalam menghasilkan laba. Analisis lingkungan internal (kekuatan dan kelemahan) membantu menemukan peluang yang menarik dan kemampuan memanfaatkan peluang tersebut. Setiap bisnis harus mengevaluasi kekuatan dan kelemahan internalnya.

Menurut Arnold (dalam Yusri, 2011) proses analisis SWOT terdiri dari tiga tahap sebagaimana berikut ini.

1. Mengidentifikasi dan membuat daftar kekuatan, kelemahan, peluang, dan ancaman.

Proses ini difokuskan pada pekerjaan internal yang dilakukan organisasi sehingga dapat memperlihatkan kekuatan dan kelemahannya, kemudian melihat hal-hal di luar organisasi yang memengaruhi secara langsung.

2. Membangun matriks SWOT, yaitu dengan memasukkan seluruh faktor kekuatan, kelemahan, peluang, dan ancaman ke kolomnya masing-masing.

3. Membuat alternatif-alternatif strategi dari penyesuaian logis faktor yang terdapat dalam kolom-kolom matriks SWOT. Ada empat kategori dasar penyesuaian yang dihasilkan matriks: SO (strengths-opportunities), ST (strengths-threats), WO (weaknessesopportunities), dan WT (weaknesses-threats). 
Berikut ini adalah tabel matriks SWOT yang digunakan dalam pembuatan alternatifalternatif strategi sebagaimana telah disebutkan diatas.

Tabel 1. Matriks SWOT

\begin{tabular}{lll}
\hline IFAS & STRENGHTS $(\mathrm{S})$ & WEAKNESSES $(\mathrm{W})$ \\
\hline EFAS & Tentukan 5-10 faktor & Tentukan 5-10 faktor \\
& kekuatan internal & kelemahan internal \\
OPPORTUNITIES (O) & STRATEGI SO & STRATEGI WO \\
Tentukan 5-10 faktor & Ciptakan strategi yang & Ciptakan strategi yang \\
peluang eksternal & menggunakan kekuatan & meminimalkan kelemahan \\
& untuk memanfaatkan & dengan memanfaatkan \\
& peluang & peluang \\
TREATHS (T) & STRATEGI ST & STRATEGI WT \\
Tentukan 5-10 faktor & Ciptakan strategi yang & Ciptakan strategi yang \\
kelemahan eksternal & menggunakan kekuatan & meminimalkan kelemahan \\
& untuk mengatasi & dan menghindari ancaman \\
& ancaman & \\
\hline
\end{tabular}

Sumber: Rangkuti (2013)

\section{METODE PENELITIAN}

Model dan metode peneltian ini bersifat deskriptif-kualitatif. Pemilihan informan dalam penelitian ini menggunakan purposive sampling (penarikan contoh bertujuan). Informan dalam penelitian ini adalah Kepala Kantor Perpustakaan Daerah Kota Tangerang Selatan, Kasie Pembinaan dan Pemberdayaan, Kasie Pengolahan dan Pengembangan Bahan Pustaka, Kasie Pelayanan dan Sistem Informasi, Kepala Sub. Bagian Tata Usaha, dan StafAhli Perpustakaan Daerah Kota Tangerang Selatan.Pihakpihak tersebut dianggap penting dan memiliki keterkaitan dengan perencanaan strategis pengembangan Perpustakaan Daerah Kota Tangerang Selatan. Metode analisis data yang digunakan bersifat induktif, dengan mengacu pada model Miles \& Huberman. Adapun teknik pengumpulan data yang digunakan dalam penelitian adalah observasi partisipatif, wawancara mendalam, dan dokumentasi.

\section{HASIL DAN PEMBAHASAN}

\section{Internal Factor Evaluation}

\section{Kekuatan}

Menurut David (2010), kekuatan adalah sumber daya, keterampilan, atau keungulankeungulan lainnya yang berhubungan dengan para pesaing perusahaan dan kebutuhan pasar yang dapat dilayani oleh perusahaan yang diharapkan dapat dilayani. Kekuatan adalah kompetisi khusus yang memberikan keunggulan kompetitif bagi perusahaan di 
pasar.Kekuatan yang terdapat padaPerpustakaan Daerah Kota Tangerang Selatan yang dapat dimanfaatkan atau dikembangkan sebagai modal landasan utama dalam penyelenggaraan tugas pokok dan fungsi perpustakaan dapat diidentifikasikan sebagai berikut.

1. Keberadaan tata kerja, tugas dan fungsi kelembagaan.Berdasarkan Peraturan Daerah Kota Tangerang Selatan No. 6 Tanggal 30 Desember Tahun 2010 tentang Organisasi Perangkat Daerah serta Peraturan Wali Kota Tangerang Selatan No. 28 Tahun 2011 tentang Tugas Pokok, Fungsi dan Tata Kerja Kantor Perpustakaan Daerah, telah dirinci bagaimana susunan, organisasi dan tata kerja kantor perpustakaan derah secara jelas. Dengan job descriptionyang jelas diharapkan seluruh pegawai perpustakaan daerah telah memahami tugas dan fungsinya masing-masing.

2. Koleksi perpustakaan daerah dengan berbagai macam dan bentuknya yang dihimpun, disusun, dan diatur sesuai dengan sistem klasifikasi dan katalogisasi bagi perpustakaan. Koleksi itu didalamnya terkandung berbagai cabang ilmu pengetahuan dan informasi untuk semua orang dalam pengertian umum, seperti anak, remaja, dewasa, pria, dan wanita. Koleksi perpustakaan adalah khasanah bangsa yang harus dipelihara, dimanfaatkan, dan dikembangkan untuk menunjang kehidupan agar lebih mudah dan sejahtera.

Tabel 2. Jumlah Koleksi Buku Perpustakaan Daerah Kota Tangsel

\begin{tabular}{lrr}
\hline \multicolumn{1}{c}{ Sumber } & $\begin{array}{c}\text { Jumlah } \\
\text { Judul }\end{array}$ & Eksemplar \\
\hline Hibah Dindik & 50 & 3.117 \\
APBD 2011 & 517 & 884 \\
APBD-P 2011 & 432 & 1.235 \\
Hibah Provinsi Perpustakaan Umum 2011 & 600 & 1.200 \\
Hibah Provinsi Perpustakaan & 725 & 1.450 \\
Hibah Perpusnas & 300 & 600 \\
APBD 2012 Buku Ilmu Pengetahuan Umum & 1.482 & 8.332 \\
APBD 2012 Ensiklopedia & 165 & 908 \\
APBD 2013 Buku Ilmu Pengetahuan Umum & 644 & 3.220 \\
APBD 2013 Buku Ilmu Pengetahuan dan & 537 & 2.685 \\
Teknologi & & \\
APBD 2013 Ensiklopedia & 29 & 103 \\
APBD 2014 Buku Ilmu Pengetahuan Umum & 783 & 2511 \\
APBD 2014 Buku Kesusastraan & 371 & 1854 \\
APBD 2014 Buku Ilmu Pengetahuan Sosial & 307 & 1535 \\
APBD 2014 Buku Ensiklopedia & 9 & 9 \\
\hline JUMLAH & $\mathbf{6 . 9 5 1}$ & $\mathbf{2 9 . 6 4 3}$ \\
\hline
\end{tabular}

Sumber: APBD Perpustakaan Daerah 2011-2014 
Tabel 3. Jumlah Koleksi Buku Perpusda Berdasarkan Klasifikasi

\begin{tabular}{cccc}
\hline No & Klas & Judul & Eksemplar \\
\hline 1 & F & 1.046 & 4.063 \\
2 & Referensi & 30 & 136 \\
3 & 000 & 382 & 1.537 \\
4 & 100 & 502 & 1.863 \\
5 & 200 & 217 & 392 \\
6 & 300 & 1.102 & 3.975 \\
7 & 400 & 78 & 457 \\
8 & 500 & 490 & 1.765 \\
9 & 600 & 1.763 & 5681 \\
10 & 700 & 383 & 1.368 \\
11 & 800 & 263 & 677 \\
12 & 900 & 346 & 1.156 \\
\hline
\end{tabular}

Sumber : APBD Perpustakaan Daerah 2012-2014

3. Pelayanan perpustakaan. Kegiatan utama Perpustakaan Daerah adalah pelayanan. Tanpa pelayanan,perpustakaan hanya gudang buku. Dalam rangka penyelenggaraan pelayanan perpustakaan perlu diketahui secara jelas arah serta tujuan yang ingin dicapai.

Tabel 4. Pelayan Perpustakaan Daerah Kota Tangsel

\begin{tabular}{|c|c|c|}
\hline No & Jenis Pelayanan & Indikator Pelayanan \\
\hline 1 & $\begin{array}{l}\text { Pelayanan di Gedung } \\
\text { Perpustakaan }\end{array}$ & $\begin{array}{l}\text { Layanan Sirkulasi, Layanan } \\
\text { Referensi, Layanan Bercerita (Story } \\
\text { Telling) }\end{array}$ \\
\hline 2 & $\begin{array}{l}\text { Pelayanan Perpustakaan } \\
\text { Keliling }\end{array}$ & 7 Kecamatan, 49 Kelurahan, 5 Desa \\
\hline 3 & Perpustakaan Digital & e-katalog \\
\hline 4 & $\begin{array}{l}\text { Publikasi, Sosialisasi, dan } \\
\text { Bimtek }\end{array}$ & $\begin{array}{l}\text { Tingkat Sekolah, Kecamatan, } \\
\text { Kelurahan, Taman Bacaan, Tempat } \\
\text { Ibadah, dan SKPD }\end{array}$ \\
\hline 5 & $\begin{array}{l}\text { Lomba Perpustakaan dan } \\
\text { Lomba Berceria }\end{array}$ & $\begin{array}{l}\text { Tingkat SD, SLTP dan SLTA, Lomba } \\
\text { Perpustakaan Sekolah, Taman } \\
\text { Bacaan, Rumah Ibadah, dan SKPD }\end{array}$ \\
\hline
\end{tabular}

Sumber: Perpustakaan Daerah Kota Tangerang Selatan 
Tabel 5. Daftar Jumlah Pengunjung Perpustakaan Daerah Kota Tangsel (2011-2013)

\begin{tabular}{cc}
\hline Tahun & Jumlah Pengunjung \\
\hline 2011 & 32.179 \\
2012 & 50.922 \\
2013 & 155.555 \\
2014 & 156.685 \\
\hline
\end{tabular}

Sumber: Perpusda 2014

4. Sarana dan Prasarana Perpustakaan. Semua fasilitas dan perlengkapan yang dimiliki merupakan daya dukung dan kekuatan dalam penyelenggaraan perpustakaan, baik dari segi jumlah, jenis, ukuran, model, tipe maupun persyaratan lainnya yang sesuai dengan perkembangan teknologi dan perubahan zaman.Semua asset yang berupa sarana dan prasarana perlu disesuaikan, sementara yang telah ada digunakan dengan baik.

5. Alokasi anggaran APBD untuk Perpustakaan Daerah Kota Tangerang Selatan yang dianggarkan setiap tahun.

\section{Kelemahan}

Kelemahan adalah keterbatasan atau kekurangan dalam sumberdaya, keterampilan, dan kapabilitas yang secara efektif menghambat kinerja perusahaan. Keterbatasan tersebut dapat berupa fasilitas, sumberdaya keuangan,kemampuan manajemen, dan keterampilan pemasaran (David, 2010). Antara kekuatan dan kelemahan yang dimiliki Perpustakaan Daerah dapat dibedakan, akan tetapi tidak dapat dipisahkan. Pada unsur yang memiliki kekuatan disatu sisi, maka sisi yang lain menjadi kelemahan. Kelemahan yang dapat diidentifikasiadalah sebagai berikut.

1. Dukungan kualitas SDM yang kurang memadaidilihat dari sisi arahan rancangan Peraturan Wali Kota tentang Organisasi dan Tata Kerja Kantor Perpustakaan Daerah. Selain itu, beban kerja dan ruang lingkup pekerjaan yang harus ditangani mengalami penumpukan beban pekerjaan pada personil tertentu. Disisi lain, seluruh formasi jabatan belum seluruhnya memiliki staf pendukung sesuai dengan uraian tugas.

2. Kurangnya SDM perpustakaan yang sesuai dengan kualifikasi.Dari sisi kualitas, SDM Kantor Perpustakaan Daerah Kota Tangerang Selatan memerlukan peningkatan kompetensi dan profesionalisme karena tidak seluruh personil memiliki latar belakang pustakawan. 
3. Belum meratanya pengembangan perpustakaan di daerahdalam hal penyediaan sumber informasi dan bahan bacaan yang sehat dan bermutu. Secara tidak langsung,perpustakaan ikut berperan dalam menyelenggarakan pendidikan, terutama yang bersifat nonformal.

4. Kurangnya sarana dan prasarana perpustakaan keliling.Pelayanan perpustakaan keliling merupakan suatu keharusan karena pada umumnya perpustakaan berlokasi di pusat kota, sementara masyarakat yang harus dilayani tersebar sampai ke pinggiran kota, dengan pertimbangan geografis dan kesibukan masyarakat sehari-hari yang tidak memungkinkan bagi mereka untuk datang ke gedung perpustakaan daerah.

5. Kurangnya publikasi dan sosialisasi minat dan budaya bacaPublikasi dan sosialisasi merupakan keharusan agar masyarakat memahami fungsi dan manfaat perpustakaan sekaligus dapat memanfaatkannya.

6. Belum adanya gedung perpustakaan.Belum adanya gedung perpustakaan yang permanen menyebabkan tidak optimalnya layanan kunjungan masyarakat Kota Tangerang Selatan ke perpustakaan daerah. 
Tabel 6. Matriks Internal Factor Evaluation

\begin{tabular}{|c|c|c|c|c|}
\hline & Faktor-Faktor Internal Utama & Bobot & Peringkat & Skor Bobot \\
\hline \multicolumn{5}{|c|}{ Kekuatan } \\
\hline 1. & $\begin{array}{l}\text { Keberadaan tata kerja, tugas, dan } \\
\text { fungsi kelembagaan }\end{array}$ & 0,10 & 3 & 0,30 \\
\hline 2. & $\begin{array}{l}\text { Koleksi perpustakaan yang } \\
\text { dihimpun, diatur, dan disusun sesuai } \\
\text { dengan sistem klasifikasi dan } \\
\text { katalogisasi perpustakaan }\end{array}$ & 0,07 & 2 & 0,14 \\
\hline 3. & Pelayanan Perpustakaan & 0,08 & 2 & 0,16 \\
\hline 4 . & $\begin{array}{l}\text { Sarana dan prasarana yang dimiliki } \\
\text { perpustaan }\end{array}$ & 0,13 & 3 & 0,39 \\
\hline 5. & $\begin{array}{l}\text { Alokasi anggaran APBD setiap } \\
\text { tahunnya untuk perpustakaan daerah }\end{array}$ & 0,06 & 2 & 0,12 \\
\hline 6. & Lokasi Perpustakaan yang Strategis & 0,14 & 4 & 0,56 \\
\hline 7. & $\begin{array}{l}\text { Mendapatkan tambahan koleksi atau } \\
\text { hibah bahan pustaka dari } \\
\text { perpustakaan nasional }\end{array}$ & 0,07 & 2 & 0,14 \\
\hline 8 . & $\begin{array}{l}\text { Layanan teknis perpustakaan } \\
\text { membuat koleksi perpustakaan } \\
\text { terpelihara dan lestari }\end{array}$ & 0,05 & 1 & 0,05 \\
\hline 9. & $\begin{array}{l}\text { Bekerja sama dengan program CSR } \\
\text { dari pihak swasta }\end{array}$ & 0,07 & 2 & 0,14 \\
\hline \multicolumn{5}{|c|}{ Kelemahan } \\
\hline & SDM yang kurang memadai & 0,03 & 4 & 0,12 \\
\hline 2. & $\begin{array}{l}\text { SDM yang tidak sesuai dengan } \\
\text { formasi }\end{array}$ & 0,02 & 3 & 0,06 \\
\hline 3. & $\begin{array}{l}\text { Belum berkembangnya perpustakaan } \\
\text { di daerah }\end{array}$ & 0,01 & 4 & 0,04 \\
\hline 4. & $\begin{array}{l}\text { Kurangnya publikasi dan sosialiasi } \\
\text { minat dan budaya baca }\end{array}$ & 0,03 & 2 & 0,06 \\
\hline 5. & Belum adanya gedung perpustakaan & 0,06 & 1 & 0,06 \\
\hline 6 . & $\begin{array}{l}\text { Hampir semua koleksi perpustakaan } \\
\text { berbentuk bahan pustaka cetak }\end{array}$ & 0,03 & 2 & 0,06 \\
\hline 7. & $\begin{array}{l}\text { Pemeliharaan dan perawatan koleksi } \\
\text { perpustakaan belum optimal }\end{array}$ & 0,02 & 4 & 0,08 \\
\hline 8 . & $\begin{array}{l}\text { Perpustakaan tidak melanggan jurnal } \\
\text { ilmiah baik cetak maupun online }\end{array}$ & 0,01 & 4 & 0,04 \\
\hline 9. & $\begin{array}{l}\text { Jenis layanan perpustakaan masih } \\
\text { terbatas pada layanan sirkulasi dan } \\
\text { Referensi }\end{array}$ & 0,02 & 3 & 0,06 \\
\hline & & 1,00 & 48 & 2,58 \\
\hline
\end{tabular}




\section{External Factor Evaluation}

Peluang

Peluang merupakan kesempatan untuk mendorong seseorang memulai usaha (Rangkuti, 2013). Kondisi eksternal yang mendukung dan dapatdimanfaatkan dalam penyelenggaraan tugas pokok dan fungsi Perpustakaan Daerah Kota Tangerang Selatan Selatandapat diidentifikasikansebagai berikut.

1. Besarnya partisipasi masyarakat terhadap perpustakaan yang tercermin dari partisipasi masyarakat dalam pelaksanaan sosialisasi perpustakaan di tingkat kelurahan dan perpustakaan keliling.

2. Banyaknya kesempatan untuk mengikuti pendidikan dan latihan perpustakaan dari Perpustakaan Nasional RI.

3. Perkembangan ilmu pengetahuan sertaperkembangan teknologi informasi dan telekomunikasi yang baik secara langsung maupuntidak langsung ikut memengaruhi kinerja perpustakaan.

4. Adanya perpustakaan sekolah, perpustakaan khusus, dan TBM.

5. Letak geografis yang mudah dijangkau.

\section{Ancaman}

Ancaman adalah suatu kecendrungan atau perkembangan yang tidak menguntungkan dalam lingkungan yang akan menyebabkan kemerosotan kedudukan perusahaan. Adapun ancaman terhadap Perpustakaan Daerah Kota Tangerang Selatan adalah sebagai berikut.

1. Munculnya pusat-pusat data informasisebagai pesaing yang dikelola oleh lembagalembaga swasta dan berorientasi profit yang kemunculannya cenderung meningkat.

2. Munculnya sejumlah pusat-pusat hiburan, seperti pusat rekreasi, acara televisi yang dikelola secara proporsional yang dapat memengaruhi masyarakat dalam mengapresiasi dan merespon kinerja perpustakaan.

3. Kurangnya budaya minat baca. Kurangnya manfaat dan pemahaman masyarakat akan perpustakaan merupakan kegiatan yang harus ditingkatkan dalam pelayanan perpustakaan. 
Tabel 7.External Factor Evaluation

\begin{tabular}{|c|c|c|c|}
\hline Faktor-Faktor Eksternal Utama & Bobot & Peringkat & Skor Bobot \\
\hline \multicolumn{4}{|l|}{ Peluang } \\
\hline $\begin{array}{l}\text { 1. Partisipasi masyarakat terhadap } \\
\text { perpustakaan Tangsel }\end{array}$ & 0,07 & 3 & 0,21 \\
\hline $\begin{array}{l}\text { 2. Banyaknya kesempatan untuk } \\
\text { mengikuti pendidikan dan latihan } \\
\text { perpustakaan }\end{array}$ & 0,04 & 1 & 0,04 \\
\hline $\begin{array}{l}\text { 3. Perkembangan ilmu pengetahuan dan } \\
\text { teknologi }\end{array}$ & 0,05 & 2 & 0,10 \\
\hline $\begin{array}{l}\text { 4. Kondisi geografis yang mudah } \\
\text { dijangkau }\end{array}$ & 0,04 & 2 & 0,08 \\
\hline $\begin{array}{l}\text { 5. Berkembangnya perpustakaan sekolah, } \\
\text { masyarakat dan perpustakaan khusus }\end{array}$ & 0,14 & 4 & 0,56 \\
\hline $\begin{array}{l}\text { 6. Adanya peningkatan jumlah pengguna } \\
\text { terutama mahasiswa yang dapat ikut } \\
\text { meningkatkan citra dan manfaat } \\
\text { perpustakaan }\end{array}$ & 0,08 & 4 & 0,48 \\
\hline $\begin{array}{l}\text { 7. Koleksi buku teks merupakan koleksi } \\
\text { perpustakaan yang paling diminati } \\
\text { oleh pengguna }\end{array}$ & 0,05 & 2 & 0,10 \\
\hline $\begin{array}{l}\text { 8. Perkembangan program studi akan } \\
\text { mendorong peningkatan jumlah koleksi } \\
\text { yang berkaitan }\end{array}$ & 0,12 & 3 & 0,18 \\
\hline $\begin{array}{l}\text { 9. Perpustakaan menjadi acuan bagi } \\
\text { masyarakat TangSel dalam pemenuhan } \\
\text { informasi }\end{array}$ & 0,06 & 2 & 0,16 \\
\hline \multicolumn{4}{|l|}{ Ancaman } \\
\hline 1. Timbulnya pusat-pusat informasi & 0,07 & 3 & 0,21 \\
\hline $\begin{array}{l}\text { 2. Timbulnya pusat-pusat hiburan dan } \\
\text { rekreasi }\end{array}$ & 0,09 & 2 & 0,18 \\
\hline 3. Kurangnya budaya minat baca & 0,12 & 1 & 0,12 \\
\hline $\begin{array}{l}\text { 4. Kurangnya ketersediaan fasilitas } \\
\text { internet }\end{array}$ & 0,07 & 4 & 0,28 \\
\hline Total & 1,00 & 33 & 2,70 \\
\hline
\end{tabular}

\section{Matriks SWOT}

Faktor linkungan internal dan eksternal pada tahap ini diperiksa dengan cermat. Dalam proses ini, data yang mendukung masing-masing faktor tersebut dikelompokkan ke dalam tabel lembar kerja kekuatan-kelemahan (S-W) dan tabel lembar kerja peluangancaman (O-T). Lembar kerja SWOT ini menggambarkan setiap kondisi perpustakaan. 
Faktor lingkungan yang akan dianalisis dalam penelitian ini adalah faktor lingkungan internal, yaitu struktur organisasi, staf, koleksi dan akses, layanan teknis dan layanan pengguna, gedung dan keuangan. Sementara faktor lingkungan eksternal adalah populasi pengguna, kebutuhan informasi pengguna, kebijakan lembaga induk, program studi, insfrastruktur teknologi, dan alokasi anggaran.

Selanjutnya adalah melakukan analisis data dengan menggunakan model perumusan matriks SWOT yang berbentuk table IFAS (Internal Strategic Factors Analysis Summary) dan EFAS (External Strategic Factors Analysis Summary) yang digunakan untuk menyususn seluruh faktor strategi SWOT. Matriks SWOT akan menghasilkan empat sel kemungkinan alternatif strategi, yaitu dengan strategi SO (kekuatan-peluang), strategi WO (kelemahanpeluang), strategi ST (kekuatang-ancaman), dan strategi WT (kelemahan-ancaman).

Tabel 8. Matriks SWOT IFAS Perpustakaan Daerah Tangsel

\begin{tabular}{llr}
\hline IFAS & \multicolumn{1}{c}{ STRENGHTS $($ S) } & \multicolumn{1}{c}{ WEAKNESSES $($ W) } \\
\hline 1. Keberadaan tata kerja, tugas dan & 1. SDM yang kurang memadai \\
fungsi kelembagaan & 2. SDM yang tidak sesuai dengan \\
2. Koleksi perpustakaan yang & formasi dan kualifikasi \\
dihimpun, diatur, dan disusun & 3. Belum berkembangnya \\
sesuai dengan sistem klasifikasi & perpustakaan di daerah \\
dan katalogisasi perpustakaan & 4. Kurangnya Publikasi, Sosialisasi \\
3. Pelayanan Perpustakaan & dan Budaya Baca \\
4. Sarana dan prasarana yang & 5. Belum adanya gedung \\
dimiliki perpustaan & perpustakaan \\
5. Alokasi anggaran APBD setiap & 6. Hampir semua koleksi \\
tahunnya untuk perpustakaan & perpustakaan berbentuk bahan \\
daerah & pustaka cetak \\
6. Lokasi Perpustakaan yang & 7. Pemeliharaan dan Perawatan \\
Strategis & buku belum maksimal \\
7. Mendapatkan tambahan koleksi & 8. Perpustakaan tidak melanggan \\
atau hibah bahan pustaka dari & Jurnal Ilmiah baik cetak maupun \\
perpustakaan nasional & online \\
8. Layanan teknis perpustakaan & 9. Jenis layanan masih terbatas pada \\
membuat koleksi perpustakaan & sirkulasi dan referensi \\
terpelihara dan lestari & \\
9. Bekerja sama dengan program & \\
CSR dari pihak swasta & \\
\hline
\end{tabular}


Tabel 9. Matriks SWOT EFAS Perpustakaan Daerah Tangsel

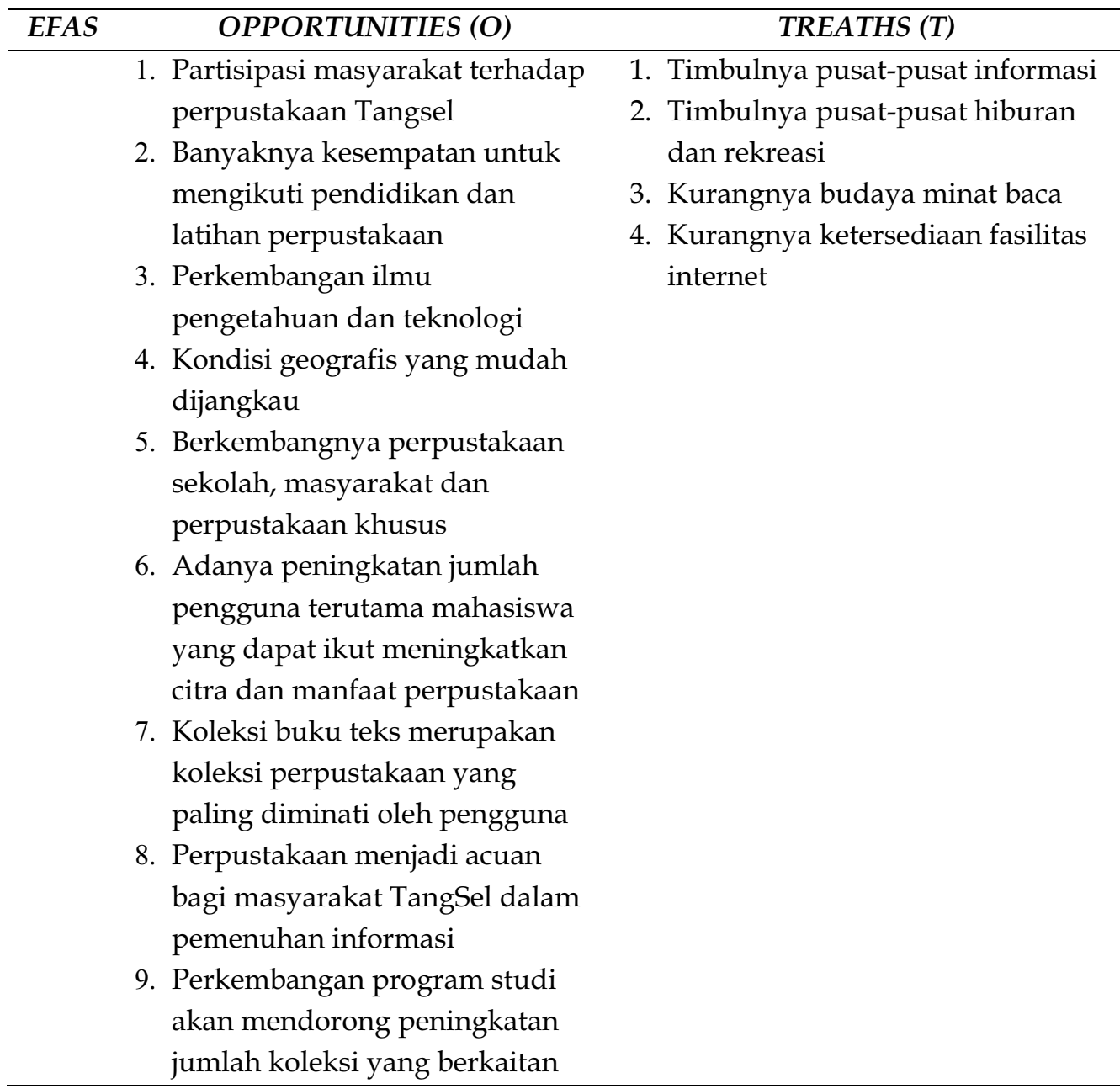




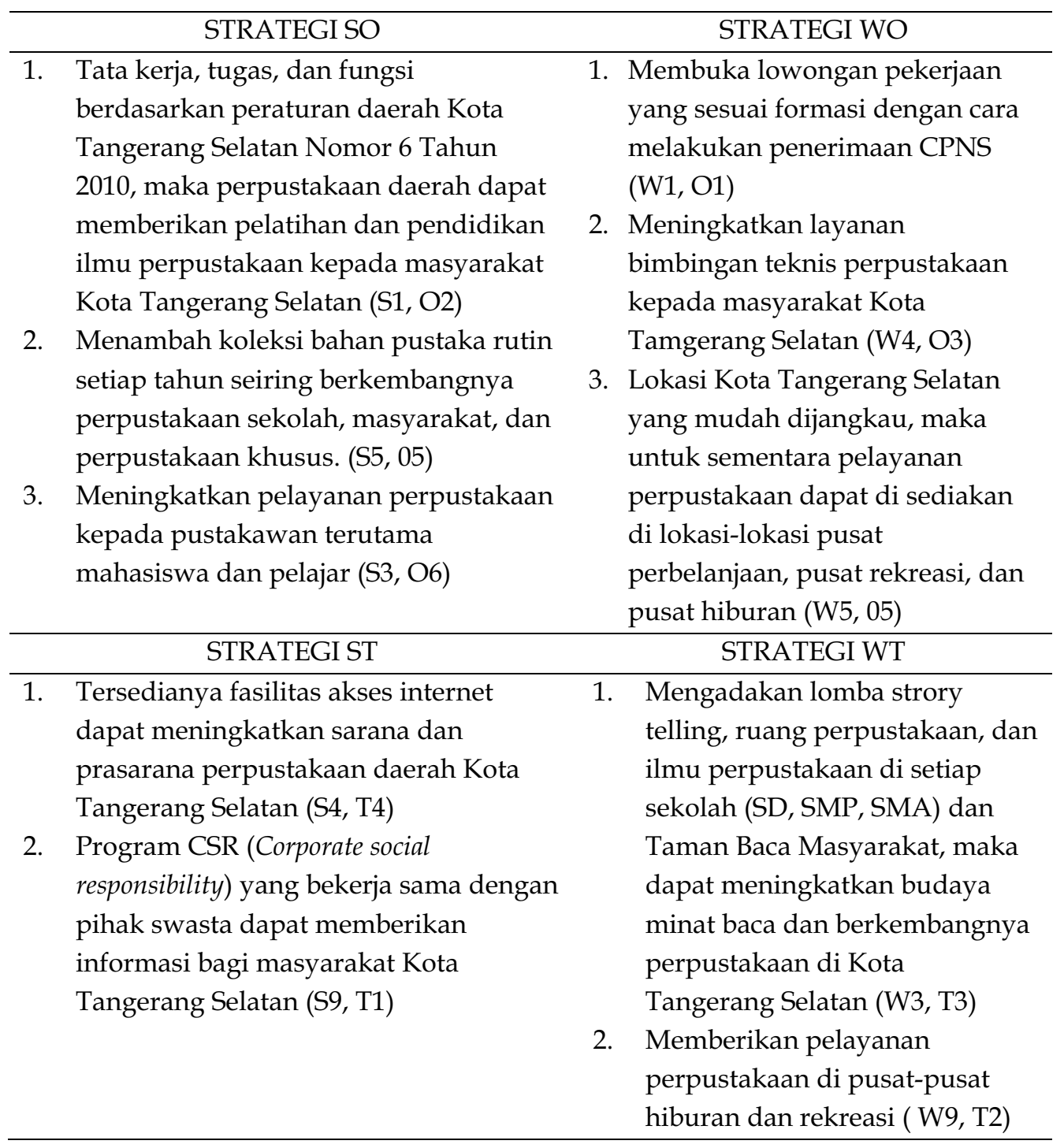

\section{Matriks IE}

Selain menggunakan matriks SWOT, penelitian ini juga menggunakan matriks IE. Menurut David (2010) matriks IE memposisikan berbagai divisi suatu organisasi dalam tampilan sembilan sel. Matriks IE menempatkan divisi-divisi organisasi dalam sebuah diagaram sistematis. Selain itu, setiap lingkaran menunjukkan persentase hasil laba dari setiap divisi.

Parameter yang digunakan meliputi parameter kekuatan internal dan pengaruh eksternal yang dihadapi. Tujuan penggunaan model ini adalah untuk memperoleh strategi bisnis di tingkat korporat yang lebih detail (Rangkuti, 2013). Matriks IFE didasarkan pada dua dimensi kunci, yaitu skor bobot IFE total pada sumbu $x$ dan skor bobot total EFE pada sumbu y (David, 2010). 
Pada sumbu x matriks IE Perpustakaan Daerah Kota Tangerang Selatan diperoleh skor bobot IFE total sebesar 2,58 yang menunjukkan posisi internal yang sedang, sementara pada sumbu y skor bobot EFE total sebesar 2,70 yang menunjukkan posisi eksternal yang sedang. Matriks IE dapat dibagi menjadi tiga bagian besar yang mempunyai implikasi strategi yang berbeda-beda.Berdasarkan total skor bobot IFE dan EFE pada Perpustakaan Daerah Kota Tangerang Selatan maka masuk ke dalam divisi sel V (David, 2010).

Skor Bobot Total IFE

\begin{tabular}{ccc}
\hline Kuat $\mathbf{3 , 0}-\mathbf{4 , 0}$ & Sedang $\mathbf{2 , 0 - 2 , 9 9}$ & Lemah $\mathbf{1 , 0 - 1 , 9 9}$ \\
\hline 3,0 & 2,0 & 1,0 \\
I & II & III \\
IV & V & VI \\
VII & VII & IX \\
\hline
\end{tabular}

Menurut David (2010), yang masuk ke dalam sel V dapat ditangani dengan baik melalui strategi menjaga dan mempertahankan. Dalam hal ini,Perpustakaan Daerah Kota Tangerang Selatan melakukan strategi intensif, yaitu dengan cara penetrasi pasar, pengembangan pasar,dan pengembangan produk.Penetrasi pasar yang harus dilakukan adalah menambah tenaga pustakawan atau memberi latihan kepada sumber daya yang sudah tersedia. Pengembangan pasar perpustakaan daerah dapat dilakukan dengan cara meningkatkan sosialisasi tentang fungsi dan manfaat perpustakaan daerah ke masyarakat Kota Tangerang Selatan. Sedangkan untuk pengembangan produk perpustakaan daerah dapat dilakukan dengan cara menambah bahan pustaka baik cetak maupun noncetak, menerbitkan bibliografi koleksi, dan koleksi khusus.

\section{Tahap Keputusan Strategi Perpustakaan Daerah Kota Tangerang Selatan}

Teknik-teknik tahap pencocokan yang dibahas dalam penelitian ini memaparkan berbagai alternatif strategi yang bisa ditempuh. Berdasarkan isu-isu strategis maka formulasi strategi yang dipilih dan dikembangkan oleh Perpustakaan Daerah Kota Tangerang Selatan adalahdengan membangun gedung baru perpustakaan dan menambah gedung perpustakaan (David, 2010). 
Tabel 10. QSPMPerpustakaan KotaTangerang Selatan

\begin{tabular}{|c|c|c|c|c|c|}
\hline \multicolumn{6}{|c|}{ Alternatif Strategi } \\
\hline & & \multicolumn{2}{|c|}{$\begin{array}{l}\text { Menambah } \\
\text { tenaga } \\
\text { pustakawan }\end{array}$} & \multicolumn{2}{|c|}{$\begin{array}{l}\text { Memberikan } \\
\text { pelatihan } \\
\text { kepada SDM } \\
\text { yang tersedia }\end{array}$} \\
\hline Faktor-Faktor Internal Utama & Bobot & AS & TAS & AS & TAS \\
\hline \multicolumn{6}{|l|}{ Kekuatan } \\
\hline $\begin{array}{l}\text { 1. Keberadaan tata kerja, tugas, dan fungsi } \\
\text { kelembagaan }\end{array}$ & 0,10 & 3 & 0,30 & 2 & 0,20 \\
\hline $\begin{array}{l}\text { 2. Koleksi perpustakaan yang dihimpun, } \\
\text { diatur, dan disusun sesuai dengan } \\
\text { sistem klasifikasi dan katalogisasi }\end{array}$ & 0,07 & 4 & 0,28 & 3 & 0,21 \\
\hline 3. Pelayanan Perpustakaan & 0,08 & 4 & 0,32 & 3 & 0,24 \\
\hline 4. Sarana dan prasarana perpustakaan & 0,13 & - & - & - & 0,24 \\
\hline $\begin{array}{l}\text { 5. Alokasi anggaran APBD setiap } \\
\text { tahunnva untuk perpustakaan daerah }\end{array}$ & 0,06 & 3 & 0,18 & 4 & - \\
\hline 6. Lokasi perpustakaan yang strategis & 0,14 & - & - & - & - \\
\hline $\begin{array}{l}\text { 7. Mendapatkan tambahan koleksi atau } \\
\text { hibah bahan pustaka dari Perpusnas }\end{array}$ & 0,07 & - & - & - & - \\
\hline $\begin{array}{l}\text { 8. Layanan teknis perpustakaan membuat } \\
\text { koleksi perpustakaan terpelihara dan } \\
\text { lestari }\end{array}$ & 0,05 & 2 & 0,10 & 3 & 0,15 \\
\hline $\begin{array}{l}\text { 9. Bekerja sama dengan program CSR dari } \\
\text { pihak swasta }\end{array}$ & 0,07 & 3 & 0,21 & 1 & 0,07 \\
\hline \multicolumn{6}{|l|}{ Kelemahan } \\
\hline 1. SDM yang kurang memadai & 0,03 & 1 & 0,03 & 2 & 0,06 \\
\hline $\begin{array}{l}\text { 2. SDM yang tidak sesuai dengan formasi } \\
\text { dan kualifikasi }\end{array}$ & 0,02 & 2 & 0,04 & 1 & 0,02 \\
\hline $\begin{array}{l}\text { 3. Belum berkembangnya perpustakaan di } \\
\text { daerah }\end{array}$ & 0,01 & 4 & 0,04 & 3 & 0,03 \\
\hline $\begin{array}{l}\text { 4. Kurangnya publikasi dan sosialiasi } \\
\text { minat dan budaya baca }\end{array}$ & 0,03 & 2 & 0,06 & 3 & 0,09 \\
\hline 5. Belum adanya gedung perpustakaan & 0,06 & 4 & 0,24 & 2 & 0,12 \\
\hline $\begin{array}{l}\text { 6. Hampir semua koleksi perpustakaan } \\
\text { berbentuk bahan pustaka cetak }\end{array}$ & 0,03 & - & - & - & \\
\hline $\begin{array}{l}\text { 7. Pemeliharaan dan perawatan koleksi } \\
\text { perpustakaan belum maksiimal }\end{array}$ & 0,02 & 2 & 0,08 & 1 & 0,02 \\
\hline $\begin{array}{l}\text { 8. Perpustakaan tidak melanggan jurnal } \\
\text { ilmiah baik cetak maupun online }\end{array}$ & 0,01 & 2 & 0,02 & 1 & 0,01 \\
\hline $\begin{array}{l}\text { 9. Jenis layanan masih terbatas pada } \\
\text { layanan sirkulasi dan Referensi }\end{array}$ & 0,02 & 2 & 0,04 & 3 & 0,06 \\
\hline TOTAL & 1,00 & & & & \\
\hline
\end{tabular}


Tabel 11. QSPM Perpustakaan Kota Tangerang Selatan

\begin{tabular}{|c|c|c|c|c|c|}
\hline \multicolumn{6}{|c|}{ Alternatif Strategi } \\
\hline & & \multicolumn{2}{|c|}{$\begin{array}{l}\text { Menambah } \\
\text { tenaga } \\
\text { pustakawan } \\
\text { perpustakaan }\end{array}$} & \multicolumn{2}{|c|}{$\begin{array}{l}\text { Memberikan } \\
\text { pelatihan } \\
\text { kepada tenaga } \\
\text { kerja yang } \\
\text { sudah ada }\end{array}$} \\
\hline Faktor-Faktor Eksternal Utama & Bobot & AS & TAS & AS & TAS \\
\hline \multicolumn{6}{|l|}{ Peluang } \\
\hline $\begin{array}{l}\text { 1. Partisipasi masyarakat terhadap } \\
\text { perpustakaan Tangsel }\end{array}$ & 0,07 & 3 & 0,21 & 1 & 0,07 \\
\hline $\begin{array}{l}\text { 2. Banyaknya kesempatan untuk } \\
\text { mengikuti pendidikan dan latihan } \\
\text { perpustakaan }\end{array}$ & 0,04 & 1 & 0,04 & 2 & 0,08 \\
\hline $\begin{array}{l}\text { 3. Perkembangan ilmu pengetahuan dan } \\
\text { teknologi }\end{array}$ & 0,05 & 2 & 0,10 & 3 & 0,15 \\
\hline $\begin{array}{l}\text { 4. Kondisi geografis yang mudah } \\
\text { dijangkau }\end{array}$ & 0,04 & 2 & 0,08 & 1 & 0,04 \\
\hline $\begin{array}{l}\text { 5. Berkembangnya perpustakaan } \\
\text { sekolah, masyarakat dan perpustakaan } \\
\text { khusus }\end{array}$ & 0,14 & 4 & 0,56 & 2 & 0,28 \\
\hline $\begin{array}{l}\text { 6. Adanya peningkatan jumlah pengguna } \\
\text { terutama mahasiswa yang dapat ikut } \\
\text { meningkatkan citra dan manfaat } \\
\text { perpustakaan }\end{array}$ & 0,08 & 4 & 0,48 & 3 & 0,24 \\
\hline $\begin{array}{l}\text { 7. Koleksi buku teks merupakan koleksi } \\
\text { perpustakaan yang paling diminati } \\
\text { oleh pengguna }\end{array}$ & 0,05 & 2 & 0,10 & 1 & 0,05 \\
\hline $\begin{array}{l}\text { 8. Perpustakaan menjadi acuan bagi } \\
\text { masyarakat TangSel dalam } \\
\text { pemenuhan informasi }\end{array}$ & 0,12 & 3 & 0,18 & 4 & 0,48 \\
\hline $\begin{array}{l}\text { 9. Perkembangan program studi akan } \\
\text { mendorong peningkatan jumlah } \\
\text { koleksi yang berkaitan }\end{array}$ & 0,06 & 2 & 0,16 & 3 & 0,18 \\
\hline \multicolumn{6}{|l|}{ Ancaman } \\
\hline 1. Timbulnya pusat-pusat informasi & 0,07 & 3 & 0,21 & 4 & 0,28 \\
\hline $\begin{array}{l}\text { 2. Timbulnya pusat-pusat hiburan dan } \\
\text { rekreasi }\end{array}$ & 0,09 & 2 & 0,18 & 3 & 0,27 \\
\hline 3. Kurangnya budaya minat baca & 0,12 & 1 & 0,12 & 2 & 0,24 \\
\hline $\begin{array}{l}\text { 4. Kurangnya ketersediaan fasilitas } \\
\text { internet }\end{array}$ & 0,07 & 4 & 0,28 & 1 & 0,07 \\
\hline TOTAL & 1,00 & & 4,64 & & 3,95 \\
\hline
\end{tabular}


Berdasarkan Tabel 11 di atas, antara jumlah keseluruhan daya tarik total sebesar 4,64 dengan 3,95, analisis tersebut mengindikasikan perlunya menambah tenaga pustakawan.

\section{PENUTUP}

\section{Kesimpulan}

Kesimpulan yang dihasilkan penelitian ini dalam menganalisis strategi Perpustakaan Daerah Kota Tangerang Selatan adalah sebagai berikut.

1. Peningkatanjenis produk dan jasa perpustakaan dapatdilakukandengan memperluas fasilitas produksi dan teknologi melalui pengembangan lingkunganeksternal dan internal. Pengembangan lingkungan eksternal dilakukandengan cara memberikan kesempatan kepada masyarakat untukmengikuti pendidikan dan pelatihan tentang perpustakaan, meningkatkan jumlah pengguna khususnya mahasiswa dan masyarakat Tangerang Selatan, dan menjadikan perpustakaan sebagai pusat informasi bagi masyarakat. Sementarapengembangan lingkungan internal dilakukandengan cara meningkatkan pelayanan perpustakaan, optimalisasi perawatan koleksi perpustakaan, dan memberikan formasi yang sesuai bagi SDM yang dimilikiPerpustakaan Daerah Kota Tangerang Selatan.

2. Selain menggunakan matriks SWOT, penelitian ini menggunakan juga matriks IE yang memposisikan berbagai divisi organisasi dalam tampilan sembilan sel. Matriks IE menempatkan divisi-divisi organisasi dalam sebuah diagaram sistematis di mana setiap lingkaran menunjukkan persentase hasil laba dari setiap divisi. Parameter yang digunakan meliputi kekuatan internal perusahaan dan pengaruh eksternal yang dihadapi. Matriks IE dapat dibagi menjadi tiga bagian besar yang mempunyai implikasi strategi yang berbeda-beda.Pada Perpustakaan Daerah Kota Tangerang Selatan, total skor bobot IFE dan EFE masuk dalam divisi sel V, yaitu dengan strategi menjaga dan mempertahankan (hold and maintain). Dalam hal ini,Perpustakaan Daerah Kota Tangerang Selatan dapatmelakukan strategi intensif melaluipenetrasi pasar, pengembangan pasar, dan pengembangan produk. Penetrasi pasar yang harus dilakukan perpustakaan adalahdengan menambah tenaga pustakawan atau memberi latihan kepada sumberdaya yang sudah tersedia. Pengembangan pasar perpustakaan dapat dilakukan dengan cara meningkatkan sosialisasi tentang fungsi dan manfaat perpustakaan daerah ke masyarakat. Sedangkan untuk pengembangan produk perpustakaan dapat dilakukan dengan menambah bahan pustaka baik cetak maupun noncetak, menerbitkan bibliografi koleksi, dan koleksi khusus.

3. Analisis dan institusimenjadi landasan bagi pengambilan keputusan perumusan strategi. Teknik-teknik tahap pencocokan yang dibahas dalampenelitian ini memaparkan berbagai alternatif strategi yang bisa ditempuh. Berdasarkan dari isuisu strategis maka formulasi strategi yang dipilih dan dikembangkan oleh perpustakaan 
daerah Kota Tangerang Selatan adalahmenambah tenaga pustakawan dan memberikan pelatihan kepada tenaga kerja yang sudah tersedia.

\section{Keterbatasan}

Penelitian ini mempunyai beberapa keterbatasan sebagai berikut ini.

1. Terbatasnya akses data yang dimiliki Perpustakaan Daerah Kota Tangerang Selatan.

2. Kurangnya Sumberdaya Manusia yang memiliki wawasan dan pengetahuan memadai tentang ilmu perpustakaan.

3. Kurang optimalnya pelayanan Perpustakaan Daerah Kota Tangerang Selatan.

4. Gedung Perpustakaan Daerah Kota Tangerang Selatan kurang sesuai dengan SNP (Standard Nasional Perpustakaan) baik di tingkat propinsi maupun Kota.

\section{Rekomendasi}

Keberadaan Perpustakaan Daerah Kota Tangerang Selatan sebagai salah satu lembaga pemerintah di bidang edukasi sudah sesuai dengan konsep yang ada, yaitu berusaha mengembangkan wawasan dan informasi bagi masyarakat Kota Tangerang Selatan. Berdasarkan hasil analisis dalam penelitian ini, berikut ini adalah beberapa rekomendasi yang dapat disampaikan.

1. Perpustakaan Daerah Kota Tangerang Selatan dapat terus mengembangkan dan meningkatkan program-program yang sesuai dengan moto Kota Tangerang Selatan, yaitu cerdas, modern, dan religius. Untuk itu, diperlukan upaya pembinaan, sosialiasi, dan publikasi secara terus menerus untuk memastikan bahwa program berjalan tepat sasaran sesuaidengan tujuan yang disepakati. Perpustakaan Daerah Kota Tangerang Selatan sebagai Satuan Kerja Perangkat Daerah (SKPD) dapat membantu pemerintah dalam membangun sistem edukasi sehingga dapat memberikan wawasan, informasi, dan manfaat yang lebih besar kepada para pemustaka dan masyarakat Kota Tangerang Selatan.

2. Perpustakaan Daerah Kota Tangerang Selatan dapat meningkatkan fasilitas, pelayananserta sarana dan prasarana agar dapat menarik budaya minat baca atau masyarakat untuk berkunjung ke perpustakaan.

3. Perpustakaan daerah Kota Tangerang Selatan dapat bekerja sama dengan pihak CSR (Corporate Soccial Responsibility) dari perusahaan swasta. 


\section{REFERENSI}

Asep, R. (2003). “Pengaruh Renovasi di Perpustakaan Fakultas Kedokteran Gigi Universitas Indonesia”. Skripsi. Depok: Fakultas Kedokteran Gigi Universitas Indonesia. BAPPEDA. (2011). Rencana Pembangunan Jangka Menengah Daerah Kota Tangerang Selatan Tahun 2011-2016. Kota Tangerang Selatan: BAPPEDA.

BPAD. (2013). Profil-profil Perpustakaan di Provinsi Banten. Badan Perpustakaan dan Arsip Daerah. Kota Tangerang Selatan: BPAD.

BPS Kota Tangerang Selatan. (2014). Kota Tangerang Selatan dalam Angka(Tangerang Selatan in Figures). Kota Tangerang Selatan: BPS.

David, F. (2010). Manajemen Strategis: Konsep. Jakarta: Salemba Empat.

Endang, S. (2009). “Sikap Murid Sekolah Dasar terhadap Layanan Perpustakaan Keliling Pemerintahan Kota Depok: Studi Kasus Di Kecamatan Cimanggis". Skripsi. Depok: Fakultas Ilmu Budaya Universitas Indonesia.

Fahmi, Y. (2011). “Perencanaan Strategis Perguruan Tinggi Islam: Studi Kasus pada Perpustakaan STAIN Padangsidimpuan". Tesis. Depok: Fakultas Ilmu Budaya Universitas Indonesia.

Hendrawan, F. (2012). “Analisis SWOT Teknik Situational Crime Prevention pada Kawasan Perumahan Industri PT. Chevron Pacific Indonesia di Duri Residential Industrial Area". Skripsi. Depok: Fakultas Ilmu Sosial dan Ilmu Politik Universitas Indonesia.

Indayati. (2008). "Faktor-faktor yang Mempengaruhi Minat Baca Mahasiswa di Perpustakaan Universitas Merdeka Madiun". Jurnal sosial, 9(2): 87-100.

Juanita, S. (2009). “Model Perencanaan Strategis Sistem Informasi atau Teknologi untuk Perguruan Tinggi". Tesis. Depok: Fakultas Ilmu Komputer Universitas Indonesia. Kotler, Philip dan Gary Amstrong. (2001). Dasar-dasar Pemasaran. Jakarta: PT. Indeks. Kotler, Philip dan Kevin Keller. (2008) Manajemen Pemasaran. Jakarta: Erlangga.

Muljono, P. (2007). "Peran Perpustakaan Umum dalam Meningkatkan Kualitas Masyarakat Pengguna: Kasus di DKI Jakarta". Jurnal Pendidikan dan Kebudayaan, No. 067, Tahun Ke-13.

Pawit, M. (2007). Pedoman Penyelenggaraan Perpustakaan Sekolah. Jakarta: Kencana.

Rangkuti, F. (2013). Teknik Membedah Analisis SWOT Cara Perhitungan Bobot, Rating dan Ocai. Jakarta: PT. Gramedia Pustaka Utama.

Renstra Perpusda. (2012). Rencana Strategies Perpustakaan Daerah Kota Tangerang Selatan. Tangerang Selatan: Perpusda Kota Tangerang Selatan.

Rodiah, N. (2011). "Pengelolaan Perpustakaan Umum: Studi Kasus di Kantor Perpustakaan Daerah Kota Bekasi". Skripsi. Depok: Fakultas Ilmu Budaya Universitas Indonesia.

Rosady, R. (2010). Metode Penelitian Public Relations dan Komunikasi. Jakarta: Rajawai Pers. 
Sugiyono. (2012). Metode Penelitian Kuantitatif Kualitatif dan RED. Bandung: Alfabeta. Sutarno, N. (2006). Manajemen Perpustakaan: Suatu Pendekatan Praktik. Jakarta: Agung Seto.

Wedhasmara, A. (2008). "Perencanaan Strategis Sistem Informasi pada Organisasi Pemerintah Daerah: Studi Kasus Pemerintah Daerah Kabupaten Purwakarta”. Tesis. Depok: Fakultas Ilmu Komputer Universitas Indonesia. 
